\title{
RESOLUTIONS
}

\section{On the Death of Samuel Hubbard Scudder.}

It is with profound sorrow that we record the death on May the 17th, 1911, of Dr. Samuel Hubbard Scudder. Born of fine lineage in the city of Boston on April the 13th, 1837, he was graduated at Williams College in 1857, taking the degree of B. A., and in 1862 from Harvard, taking the degree of B. S. He was one of the favorite pupils and assistants of the late Professor Louis Agassiz. He was the Secretary of the Boston Society of Natural History from 1862 until 1870, during much of this period being also the Curator of the Museum; and from 1880 to 1887 he served as the President of the Society. From 1879 to 1882 he was the Assistant Librarian of Harvard University. From 1886 to 1892 he held the position of Paleontologist of the United States Geological Survey. His scientific and literary industry was prodigious. His entomological works deal principally with the Lepidoptera, the Orthoptera, and fossil insects. He placed American biologists under everlasting indebtedness to him by the preparation of the "Nomenclator Zoologicus", and by many bibliographies and indices. His great work "The Butterflies of the Eastern United States and Canada with special Reference to New England", and his magnificent volumes upon the "Pretertiary and Tertiary Fossil Insects of North America" will always remain classical. Honors were abundantly bestowed upon him by learned societies both in America and Europe, and he received many richly deserved academic degrees.

Reviewing his work in its entirety, it constitutes one of the most notable contributions made by a single individual to the literature of biological science during the past fifty years. It is a monument attesting the vast learning and the colossal industry of a man, who in circumstances which did not entail upon him the necessity for labor, dignified his life by consecrating his noble powers to the advancement of human knowledge. Though suffering the keenest domestic bereavements, and during the last years of his life compelled to undergo a living martyrdom through paralysis both of hands and feet, he preserved to the last his cheerful disposition and an unclouded intellect. His death came as a gentle release from suffering, leaving our Society and the world the richer by his example of patience and the fruits of his toil; the poorer by his removal hence.

(Signed)

W. J. Holland,

C. J. S. Bethune. 


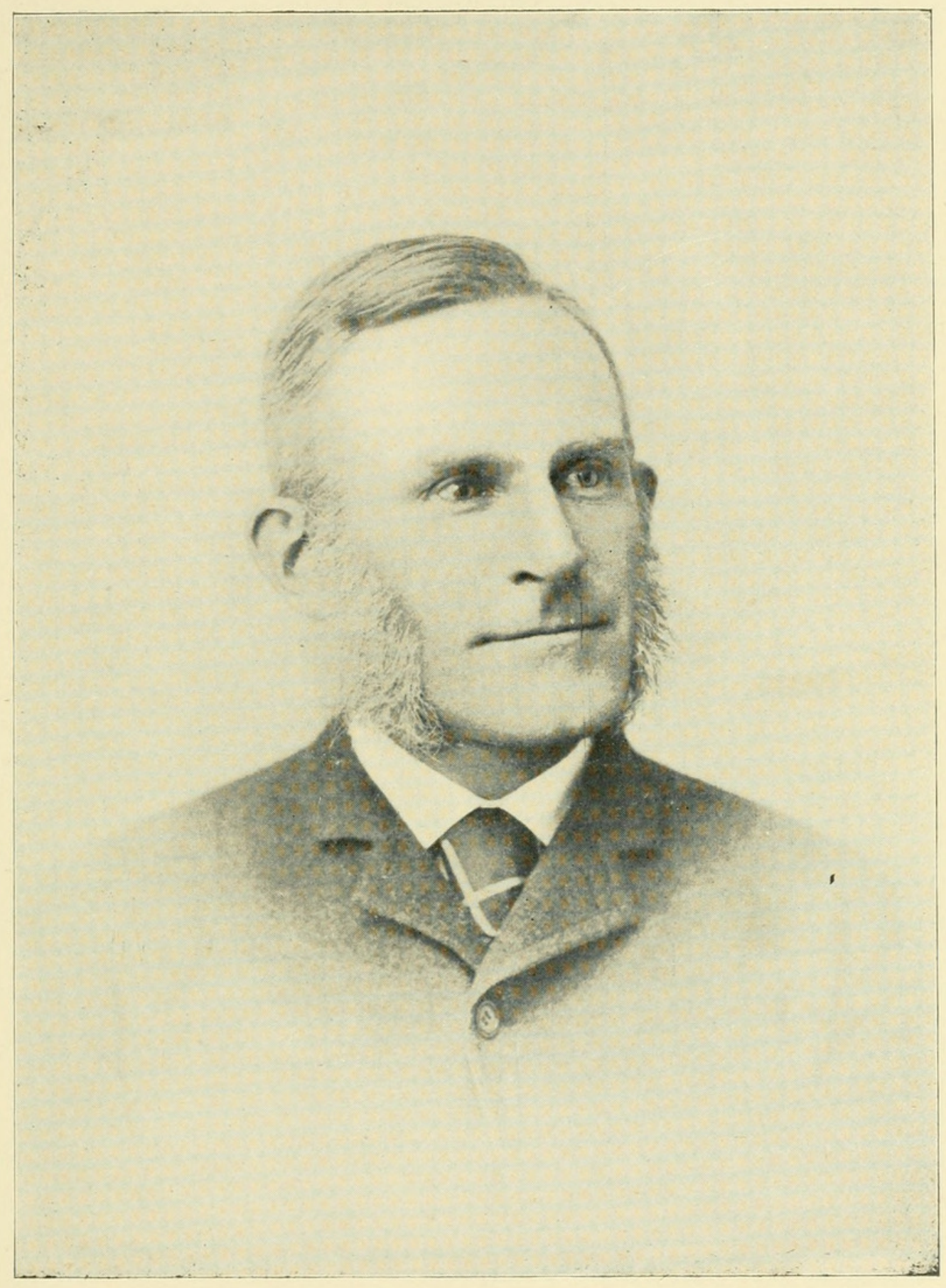

DR. S. H. SCUDDER

Plate III 




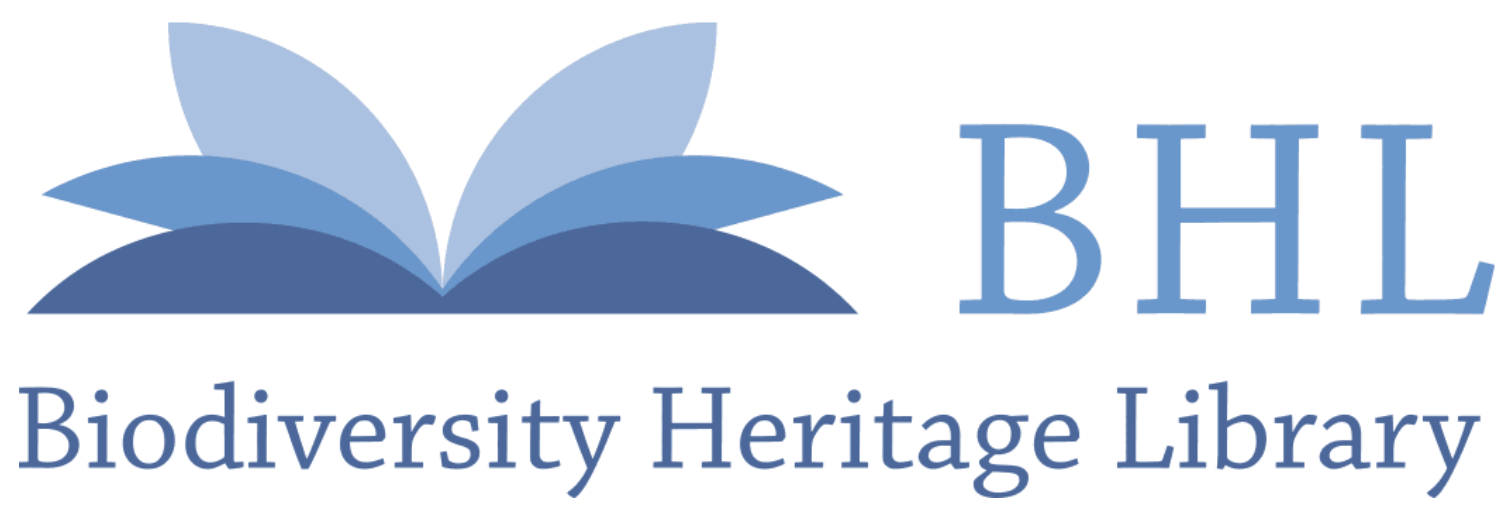

1912. "Resolutions: On the Death of Samuel Hubbard Scudder." Annals of the Entomological Society of America 5, 72-75. https://doi.org/10.1093/aesa/5.1.72.

View This Item Online: https://www.biodiversitylibrary.org/item/43634

DOI: https://doi.org/10.1093/aesa/5.1.72

Permalink: $\underline{\text { https://www.biodiversitylibrary.org/partpdf/193595 }}$

\section{Holding Institution}

Smithsonian Libraries

\section{Sponsored by}

Smithsonian

\section{Copyright \& Reuse}

Copyright Status: NOT_IN_COPYRIGHT

This document was created from content at the Biodiversity Heritage Library, the world's largest open access digital library for biodiversity literature and archives. Visit BHL at https://www.biodiversitylibrary.org. 